\title{
Performance analysis of grid-tied photovoltaic system under varying weather condition and load
}

\author{
Abayomi A. Adebiyi ${ }^{1}$, Ian J. Lazarus ${ }^{2}$, Akshay K. Saha ${ }^{3}$, Evans E. Ojo ${ }^{4}$ \\ ${ }^{1,4}$ Department of Electrical Power Engineering, Durban University of Technology, South Africa \\ ${ }^{2}$ Department of Physics, Durban University of Technology, South Africa \\ ${ }^{3}$ School of Engineering, Howard College, University of KwaZulu-Natal, South Africa
}

\begin{tabular}{l} 
Article Info \\
\hline Article history: \\
Received Mar 4, 2020 \\
Revised Jun 20, 2020 \\
Accepted Jul 8, 2020 \\
\hline
\end{tabular}

\section{Keywords:}

DC-DC converter Incremental conductance MPPT algorithm Photovoltaic (PV) system Voltage variation

\begin{abstract}
Model and simulation of the impact of the distribution grid-tied photovoltaic (PV) system feeding a variable load with its control system have been investigated in this study. Incremental Conductance (IncCond) algorithm based on maximum power point tracking (MPPT) was implemented for the PV system to extract maximum power under different weather conditions when solar irradiation varies between $250 \mathrm{~W} / \mathrm{m}^{2}$ and $1000 \mathrm{~W} / \mathrm{m}^{2}$. The proposed system is modelled and simulated with MATLAB/Simulink tools. Under different weather conditions, the dynamic performance of the PV system is evaluated. The results obtained show the efficacy of the proposed MPPT method in response to rapid daytime weather variations. The results also show that the surplus power generated is injected into the grid when the injected power from the PV system is higher than the load demand; otherwise, the grid supplies the load.
\end{abstract}

This is an open access article under the CC BY-SA license.

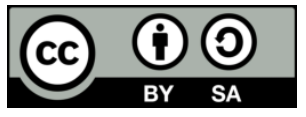

\section{Corresponding Author:}

Abayomi A. Adebiyi,

Department of Electrical Power Engineering,

Durban University of Technology,

Steve Biko Campus, Berea, Durban, 4001, South Africa.

Email: abayomia@dut.ac.za

\section{INTRODUCTION}

The intense global effort to promote, develop, and implement renewable energy technologies is a characteristic of the early twenty-first century. The primary objective of this policy drive is to reduce the reliance on and use of increasingly non-replenishing fossil fuel resources to mitigate the emission of greenhouse gases globally. In Q3 2019, the US added 2.6 gigawatts (GW) of solar photovoltaic power, which bring the installed capacity to $71.3 \mathrm{GW}$, adequate to supply 14.5 million homes in America [1]. India sets the highest global target of installing $175 \mathrm{GW}$ of renewable energy generation by 2021-2022. It was reported $\mathrm{n}$ [2] that $100 \mathrm{GW}$ would be generated from solar energy, with a target of $40 \mathrm{GW}$ of distributed rooftop solar PV systems to mitigate grid losses and constant power interruptions in the country. South Africa has published its 2019 integrated resource plan (IRP), a policy guide to becoming self-sufficient and competitive in its future energy mix [3]. A significant focus is on wind and solar photovoltaic systems. By 2030, it is anticipated that solar PV will contribute $10.5 \%$ of the country's total energy mix [4], as presented in Figure 1. The gradual transition to a renewable energy future and the green economy are plausible and achievable. The generation of solar energy from solar irradiation, one of the many alternatives for generating power, has grown significantly owing to the ever-increasing demand for energy, providing a renewable as well as an environmentally friendly energy source. Its source is intermittent and is heavily dependent on climate conditions; also, the photovoltaic energy source is accessible only during the daytime $[5,6]$. The challenge of 
integrating intermittent energy sources arises from the fact that the concept of the grid is around massive and controllable power generators. Presently, a three-phase planning process is used by the grid operators to ensure that utilities produce at the right time the right amount of electricity to meet efficiently and effectively electricity demand. Since the grid has insufficient storage capacity, the equilibrium between supply and demand for electricity must be sustained at all times to prevent a collapse and other rippling problems [7, 8].

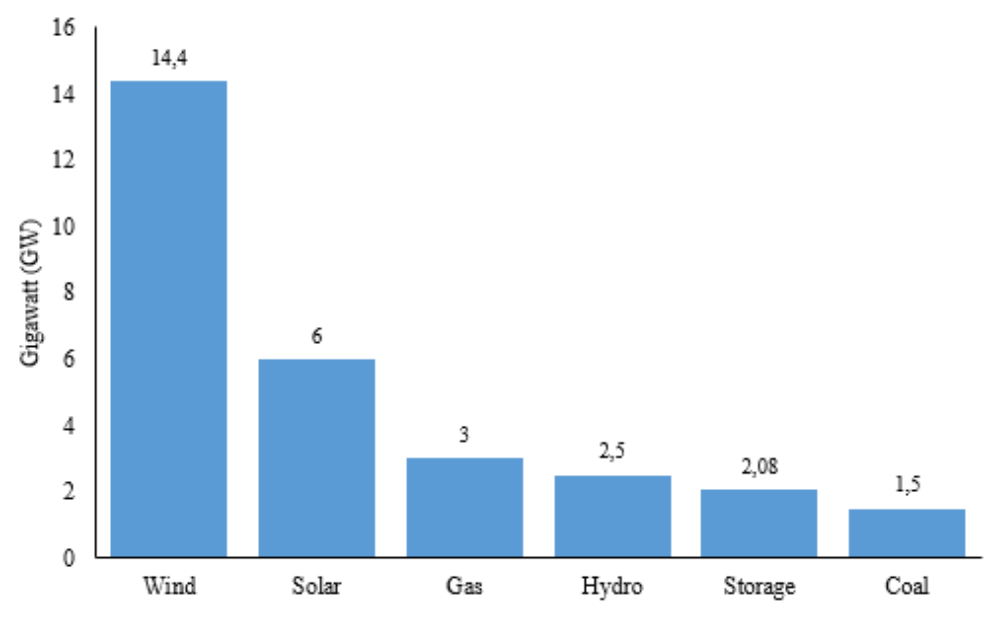

Figure 1. South Africa energy target until 2030 [3]

\section{REVIEW OF RELATED LITERATURE}

Reactive power and voltage control [9-13] and PV system power curtailment [14-16] are proposed methods in the existing literature to improve the distribution grid voltage profile and reduce observed overvoltage during variation of generated power by the grid-tied PV system. Since the power, the PV system produces depends much on weather conditions, like solar radiation and temperature, which varies. Hence it is crucial to implement maximum power point tracking (MPPT) technique to draw maximal power under changing environmental conditions [17]. Some research studies on MPPT control methods have been reviewed. MPPT algorithms for PV system based on particle swarm optimization (PSO) were investigated in [18]; comparisons of results on maximum power point (MPP) behaviour under uniform and non-uniform operating conditions to select the optimal duty-cycle were simulated in [19]. Experimental implementation and simulation of a novel InCond MPPT variable step-size algorithm for the PV system were compared in [20]. Comparative analysis of the perturb and observe (P\&O) and incremental conductance (InCond) MPPT algorithms was discussed in [21]. The simulation results show that the InCond method performs better than the P\&O algorithm. The PV system steady-state and dynamics performance improve with these algorithms. Lately, some challenges have arisen in the grid-tied PV system, which needs consideration. These challenges include the issue of power quality, maximum power extraction, and the issue of high-level penetration of the PV system on the distribution network under varying weather conditions [22-24].

A comprehensive dynamic model and regulation of a grid-tied PV system that supplies variable loads are investigated in this study. The proposed system consists of two PV systems that are integrated into the grid at different locations to enhance the efficiency of the system. The motivation for this study is to investigate PV systems performance under different climatic conditions, particularly variations in solar radiation and temperature. The InCond MPP extraction algorithm is designed on the two grid-tied PV systems to obtain the maximum power under varying weather conditions.

\section{SYSTEM MODEL DESIGN}

Figure 2 presents a schematic of the PV system concept. The proposed system has two different PV power plants that penetrate the grid at different points, integrating the network on the $25 \mathrm{kV}$ bus-bar via a two-stage converter at the point of common coupling (PCC). The two installed PV power plants (systems A and $\mathrm{B}$ ) receive a different level of solar radiation at their various locations. The PV system injects power into the grid with a plant of variable loads, which consists of six induction motor, each having 2 MVA rating. The PV system feeds the network with surplus power when the PV systems generate electricity higher than the demand for the load. Alternatively, the grid feeds the loads in combination with the PV system when 
the power from the PV system is less than the load requirement. Likewise, the grid supplies the loads when the injected power from the PV system is not available.

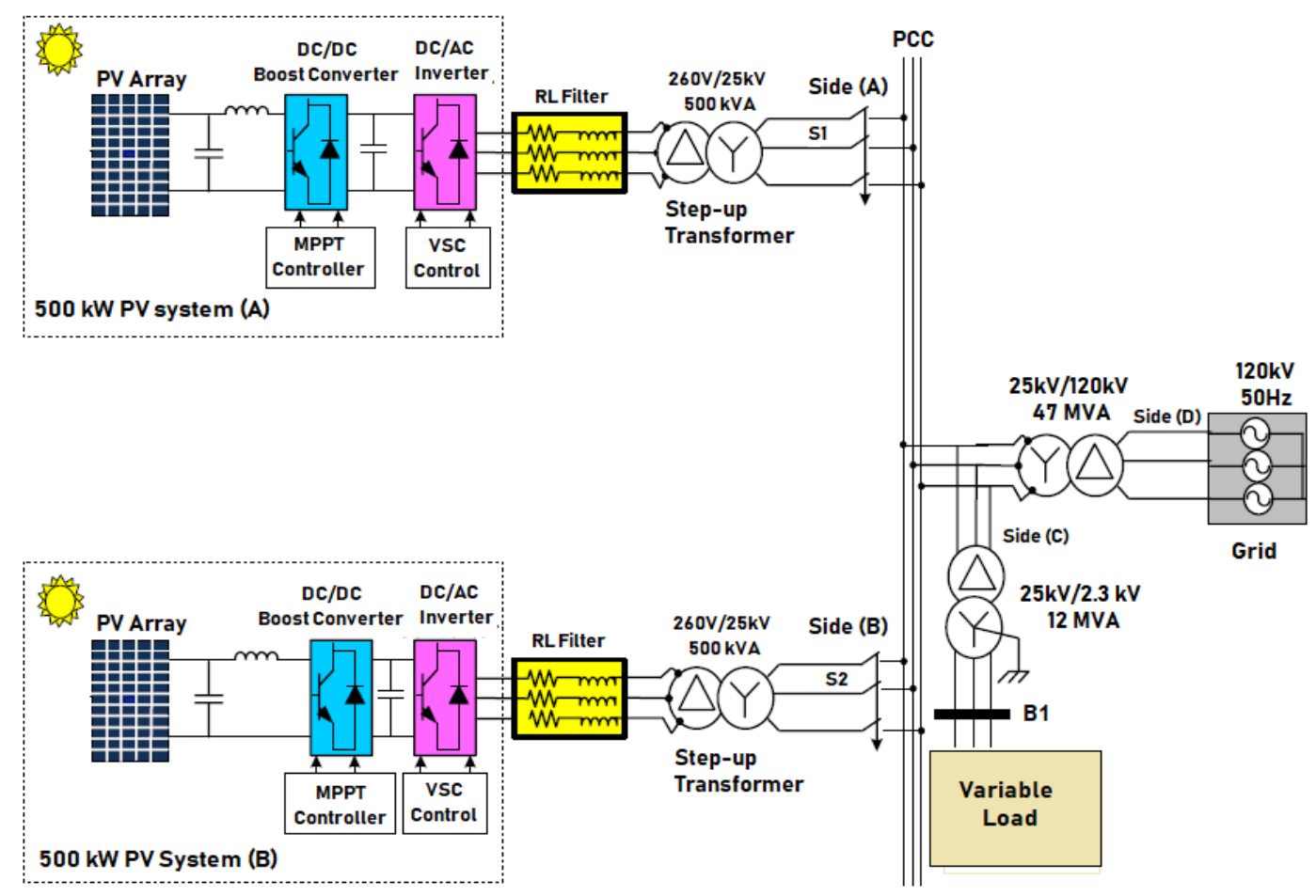

Figure 2. PV system model design

\section{METHODOLOGY}

The proposed methodology focuses on the control of the injected active power, reactive power, and current into the grid. The PV system consists of a PV array, a DC-DC boost converter with an MPPT controller, a three-phase voltage source inverter, a PWM block, an RL filter, and the grid with the load. The grid-tied PV system has been modelled and simulated with Simulink.

\subsection{Photovoltaic modelling}

The PV array model presented in Figure 3 based on the Shockley diode $[25,26]$ was implemented for this study. The model consists of PV panels connected in series to form a string, and the PV strings are connected in parallel to create the PV array required for the boost converter input. The characteristic equation of the PV array current and voltage is expressed in (1) to (4). The simulation curves of current-voltage (I-V) and power-voltage $(\mathrm{P}-\mathrm{V})$ for specific solar radiation values were obtained and presented in Figures 4 and 5.

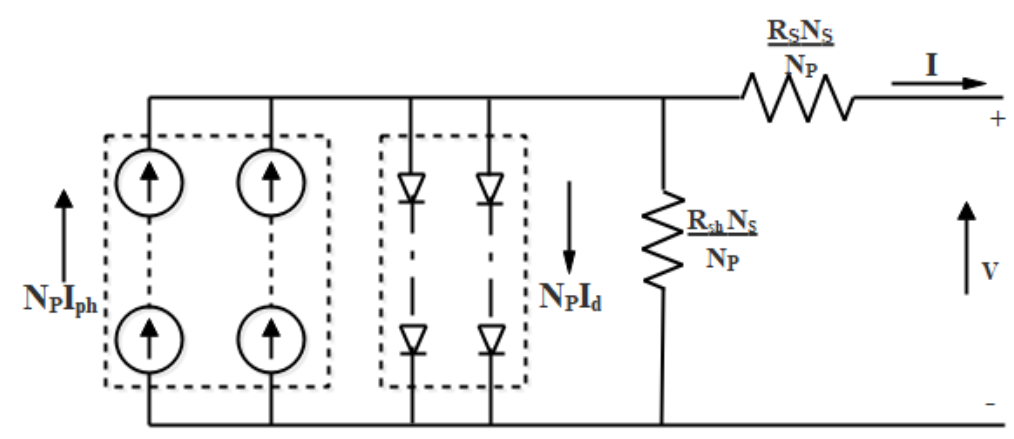

Figure 3. PV array model 


$$
\begin{aligned}
& I=N_{p} I_{p h}-N_{p} I_{s}\left\{\exp \left(\frac{\left[q \frac{V}{N_{s}}+R_{s} I\right]}{k T A}\right]-1\right\}-\left(\frac{\frac{N_{p} V}{N_{s}}+R_{s} I}{R_{s h}}\right) \\
& I_{p h}=\frac{G}{1000}-\left(I_{s c}+K_{i}\left[T-T_{r e f}\right]\right) \\
& I_{s}=I_{r s}\left(\frac{T}{T_{r e f}}\right)^{3} \exp \left[\frac{q E g}{k A}\left(\frac{1}{T_{r e f}}-\frac{1}{T}\right)\right] \\
& V_{O C}=\frac{n k T}{q} \operatorname{In}\left(\frac{I_{p h}}{I_{0}}+1\right)
\end{aligned}
$$

where $I_{p h}$ is the PV array output load current (A), $\mathrm{I}_{0}$ is the saturation current, $G$ is the solar radiation intensity, $N_{s}$ is the number of series PV cells, and $N_{p}$ is the number of parallel PV cells. $q$ is the electron charge; $A$ is the diode ideality constant, $K$ is the Boltzmann constant. $T[\mathrm{~K}]$ is the temperature of the $\mathrm{p}-\mathrm{n}$ junction, $T_{\text {ref }}[\mathrm{k}]$ is the reference temperature, $V$ is $\mathrm{PV}$ array output voltage $(\mathrm{V}), R_{s}$ is series resistance, and $R_{s h}$ is shunt resistance [5].

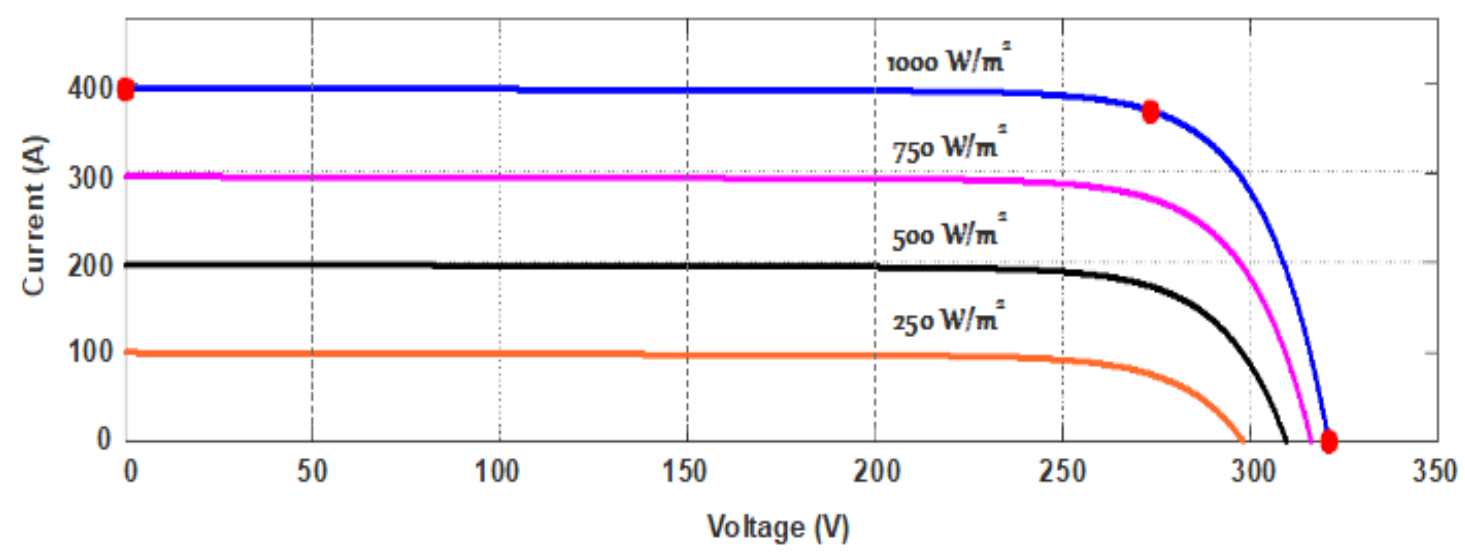

Figure 4. Current verse voltage characteristic

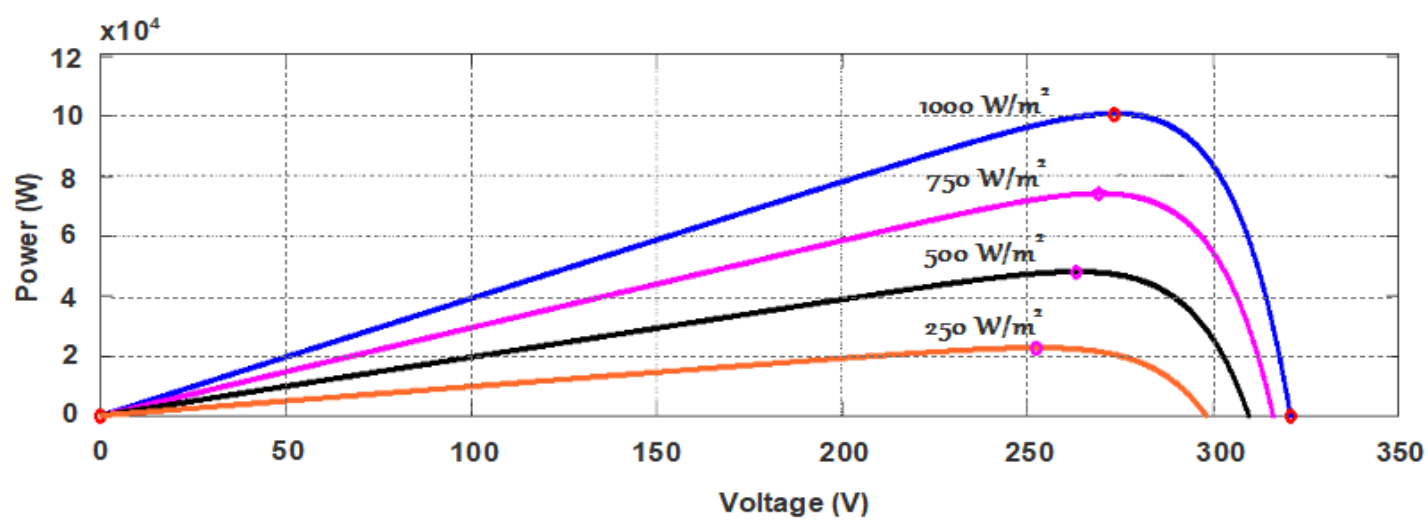

Figure 5. Power verse voltage characteristic for specific irradiation values 
Figures 4 and 5 presents the PV array estimated terminal characteristics derived by applying (2) and (4) for the short-circuit current and open-circuit voltage. The detailed specification of each PV panel is given in Table 1. The PV array short-circuits current is proportional to the solar radiation received, and the opencircuit voltage slightly increases with increasing solar radiation. A PV array I-V and P-V characteristics are nonlinear, as shown in Figures 4 and 5. The nonlinear behaviour is primarily due to the diode current's nonlinear characteristics. Consequently, maximum power is extracted from the PV system when operating at the maximum power point (MPP) voltage.

Table 1. Detail description of the PV panel used [6]

\begin{tabular}{ll}
\hline Description & Parameter \\
\hline Module type & SunPower SPR-305-WHT \\
Voltage at Peak Power $\left(\mathrm{V}_{\max }\right)$ & $54.7 \mathrm{~V}$ \\
Current at Peak Power $\left(\mathrm{I}_{\max }\right)$ & $5.58 \mathrm{~A}$ \\
Short-Circuit Current $\left(\mathrm{I}_{\mathrm{SC}}\right)$ & $5.96 \mathrm{~A}$ \\
Open Circuit Voltage $\left(\mathrm{V}_{\mathrm{OC}}\right)$ & $64.2 \mathrm{~V}$ \\
Number of cell per module & 96 \\
Number of series module connect per string & 6 \\
Number of array per system & 5 \\
Maximum Power per array $\left(\mathrm{P}_{\max }\right)$ & $100.6 \mathrm{~kW}$ \\
Peak Efficiency & $18.7 \%$ \\
Power Tolerance & $\pm 5 \%$ \\
\hline
\end{tabular}

\subsection{Maximum power point tracking algorithm}

The characteristics of PV cells determine the maximum available power to the DC-DC converter. Still, this value often mismatches the load MPP due to moving cloud and changes in solar radiation, which prevents the extraction of the maximum system power. The PV array MPP can be maintained at the maximum point by implementing an MPPT algorithm in PV systems, which optimizes the PV system energy yield. Incremental Conductance (InCond) MPPT algorithm was implemented in this study because it offers exceptional performance under rapidly changing weather conditions [19]. The MPPT controller observes the array output current and voltage to calculate the conductance and incremental conductance before deciding to raise or reduce the output of the converter duty ratio. The InCond MPPT method relies on the assumption that, at the maximum power point (MPP), the slope of the P-V curve is equal to zero. Besides, the voltage power derivative $\left(d \mathrm{P}_{\mathrm{pv}} / d \mathrm{~V}_{\mathrm{pv}}\right)$ is negative on the right of the MPP and positive on the left of the MPP. The theory of the InCond algorithm is expressed in (5) to (14) [19].

$$
P=I * V
$$

The product derivative sequence of $\mathrm{P}=\mathrm{I} * \mathrm{~V}$ yield:

$$
\begin{aligned}
& \frac{\delta P}{\delta V}=\frac{\delta}{\delta V}(I * V) \\
& =I \frac{\delta V}{\delta V}+V \frac{\delta I}{\delta V} \\
& =I+V \frac{\delta I}{\delta V} \\
& \frac{\delta P}{\delta V}=0, \quad \frac{\delta I}{\delta V}=-\frac{I}{V} \quad \text { at } \mathrm{MPP}, \Delta \mathrm{V}=0
\end{aligned}
$$

We define the decreasing conductance $(-\mathrm{I} / \mathrm{V})$ as $\mathrm{G}$ and the increasing conductance $(d \mathrm{I} / d \mathrm{~V})$ as $\Delta \mathrm{G}$.

$$
\begin{aligned}
& G=-I / V \\
& \Delta G=\delta I / \delta V
\end{aligned}
$$


The InCond algorithm controls the PV point of operating voltage, where the conductance is directly proportional to the incremental conductance. This concept is presented by (12), (13), and (14) and is shown graphically in Figure 6. Figure 7 presents the InCond MPPT algorithm flow chart, while Figure 8 depicts the Simulink model implementation of the algorithm.

$$
\begin{array}{ll}
\frac{\delta P}{\delta V}>0, & \text { if } G>\Delta G \\
\frac{\delta P}{\delta V}=0, & \text { if } G=\Delta G \\
\frac{\delta P}{\delta V}<0, & \text { if } G<\Delta G
\end{array}
$$

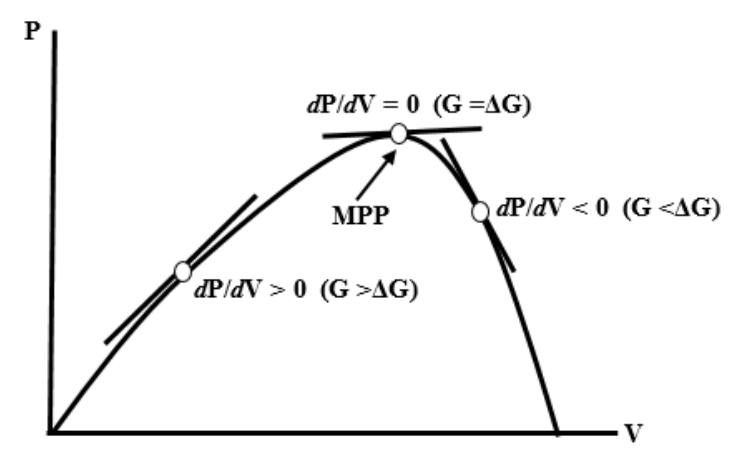

Figure 6. InCond MPPT operation

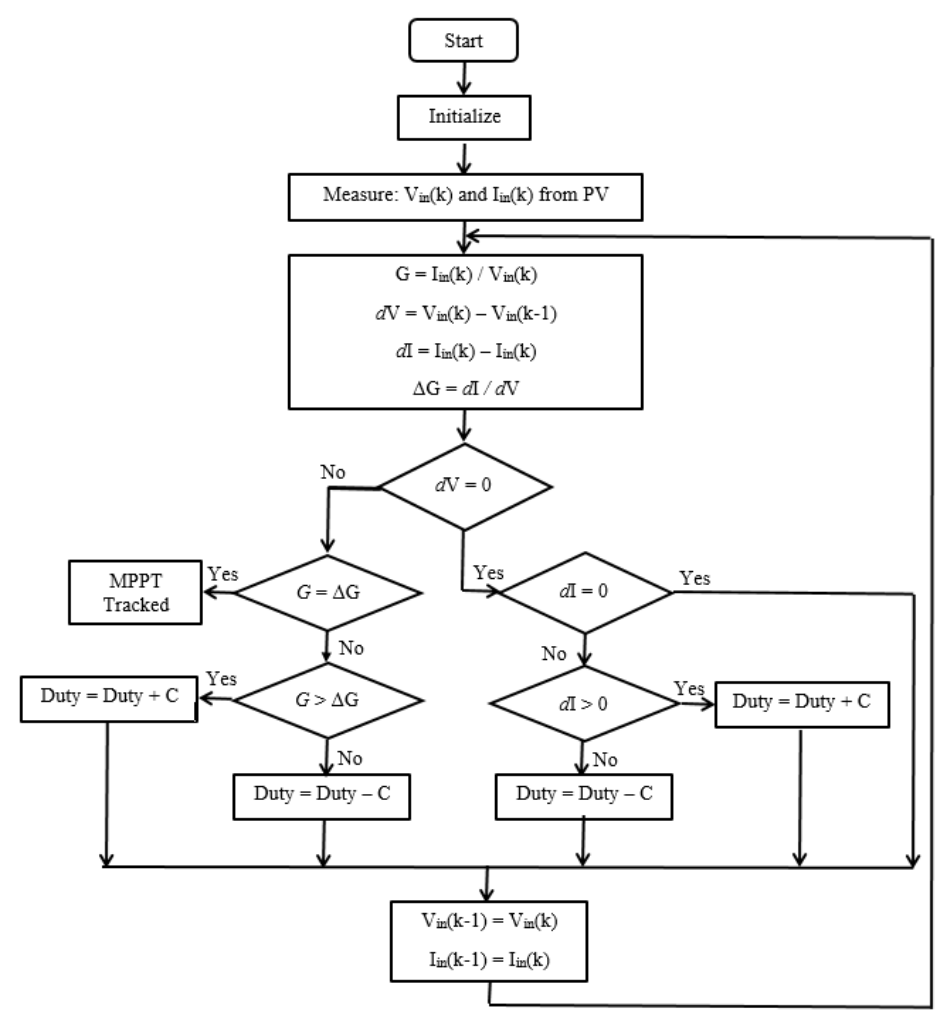

Figure 7. Incremental conductance algorithm flowchart 


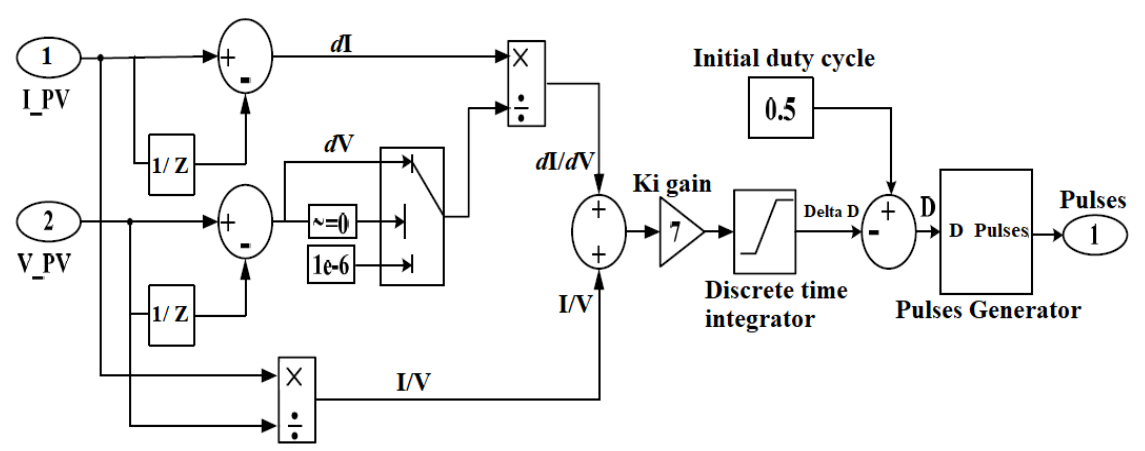

Figure 8. PV MPPT control model

\subsection{Inverter controller}

This study utilized a three-phase two-level inverter to connect the PV system to the grid. The inverter control system is shown in Figure 9. The Voltage-Source Control (VSC) technique is used to regulate the voltage of the DC-link at a steady rate, to control the reactive power injected into the grid, control DC bus voltage, and keep the PCC bus power factor at unity [27]. The d-q synchronous rotating reference frame of the inverter voltage is defined as follows:

$$
V_{a b c}=V_{a b c_{-} i n v}-R_{f} \cdot I_{a b c_{-} i n v}-L_{f} \frac{d I_{a b c_{-} i n v}}{d t}
$$

Solving (15) yields the d-q rotating reference frame:

$$
\begin{aligned}
& V_{d_{-} i n v}=V_{d}+R_{f} I_{d}+L_{f} \frac{d I_{d}}{d t}-\varpi L_{f} I_{q} \\
& V_{q_{-} i n v}=V_{q}+R_{f} I_{q}+L_{f} \frac{d I_{q}}{d t}+\varpi L_{f} I_{d}
\end{aligned}
$$

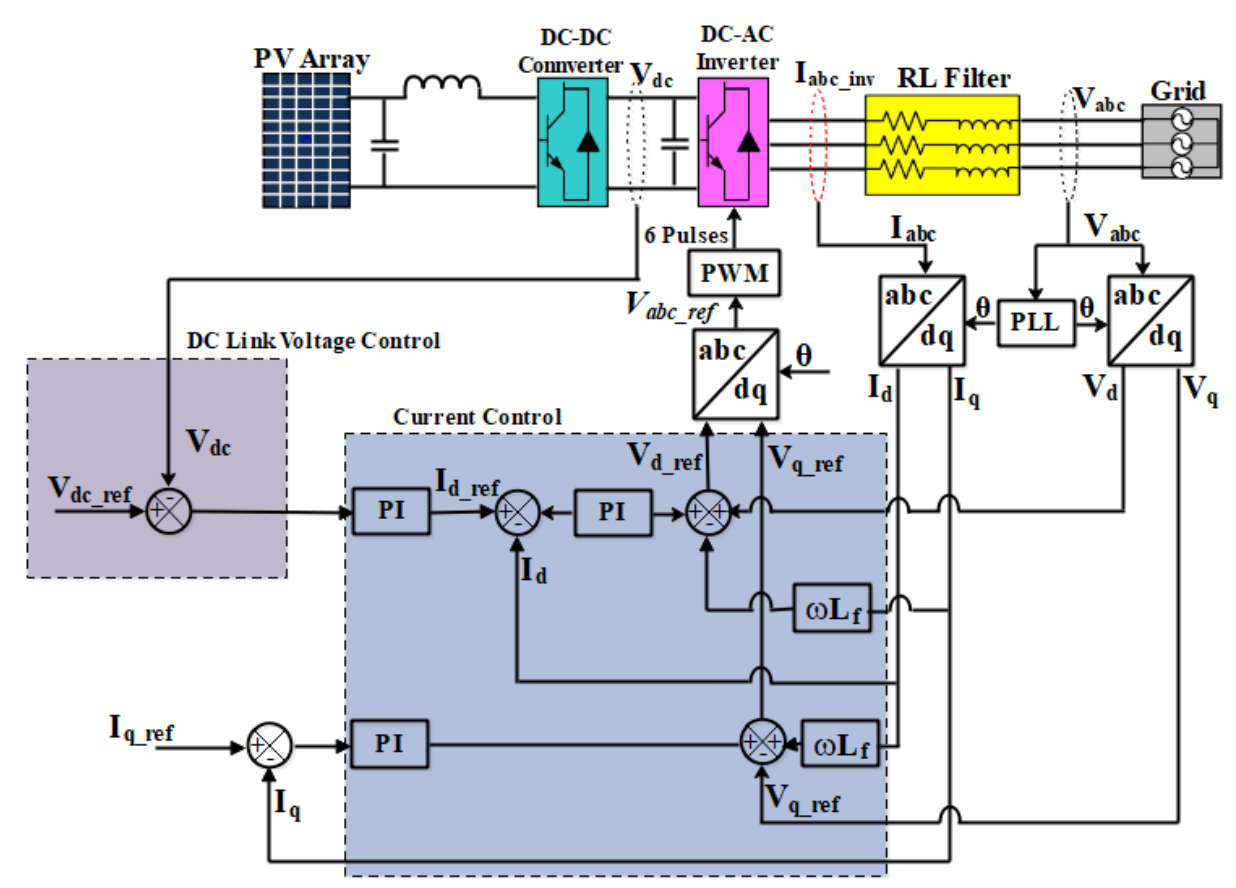

Figure 9. The inverter control scheme 
The inverter controller's main components are the phase locked loop (PLL), the current control and, the DC-link voltage controller. The PLL generates the grid voltage angle $(\theta)$ used for the transformation of $\mathrm{abc} / \mathrm{d}-\mathrm{q}$, and it synchronizes the inverter output voltage $\left(\mathrm{V}_{a b c-i n v}\right)$ with the grid current and PCC bus voltage [27], is shown in Figure 10. The system consists of a current control loop that allows the current generated to the grid $\left(I_{d}\right.$ and $\left.I_{q}\right)$ to tracks the reference current $\left(I_{d r e f}\right.$ and $I_{q}$ ref $)$ that is generated by the $a b c$ to $d-q$ transformation to keep the DC link voltage at a constant value. The inverter q-axis current reference $\left(I_{q_{-}} r f\right)$ is set to zero so that the PV system can maintain the unity power factor. The DC link voltage $\left(V_{d c}\right)$ compares with the reference voltage $\left(V_{d c-r e f}\right)$, and the error is input to a Proportional-Integral (PI) controller to regulate the voltage. Thereafter, the inverter current $\left(I_{d}\right.$ and $\left.I_{q}\right)$ is compared to the current reference $\left(I_{d_{-}}\right.$ref and $I_{q_{-}}$ref); then, the difference is inputted into the PI controller to generate the voltage reference component of the inverter $\left(V_{d_{-} r e f}\right.$ and $\left.V_{q_{-} r e f}\right)$. The voltage reference $\left(V_{d_{-} r e f}\right.$ and $\left.V_{q_{-} r e f}\right)$ is transformed into three-phase voltage reference $\left(V_{a b c \_}{ }_{2}\right)$ that is applied to the pulse width modulator (PWM) to generate the switching pulses for inverter IGBT switches. Therefore, $\left(I_{d}\right.$ and $\left.I_{q}\right)$ can independently adjust the active and reactive power (P-Q) fed to the grid, respectively [28] as expressed in (18) and (19).

$$
\begin{aligned}
& P=\frac{3}{2}\left(V_{q} I_{q}+V_{d} I_{d}\right)=\frac{3}{2} V_{d} I_{d} \\
& Q=\frac{3}{2}\left(V_{d} I_{q}-V_{q} I_{d}\right)=-\frac{3}{2} V_{d} I_{q}
\end{aligned}
$$

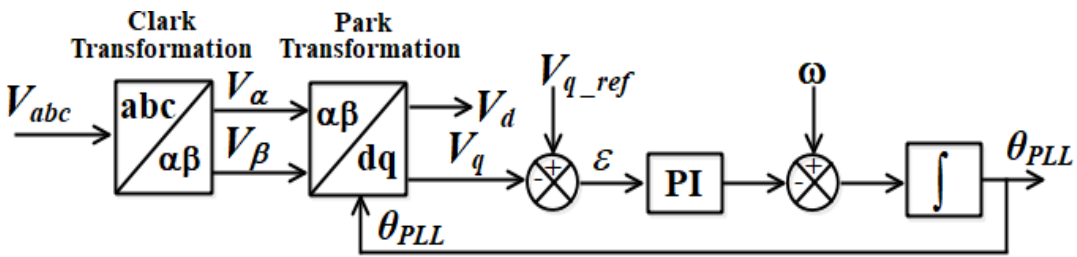

Figure 10. Phase-locked loop block diagram

\section{RESULTS AND DISCUSSION}

This section discusses the analysis of PV systems performance under different weather conditions, such as solar radiation variations on the grid. The results of the PV system model simulation show that the desired system performance was achieved successfully with the proposed control methods.

\subsection{Performance of PV System}

\subsubsection{Comparison of with and without MPPT method}

A comparison is made based on the effect of variability in solar radiation observed with and without the InCond MPPT algorithm. It is observed that there is a significant improvement in the power injected from the PV array with the MPPT algorithm as compared with the case when the MPPT algorithm is disabled. The result is presented in Figure 11.

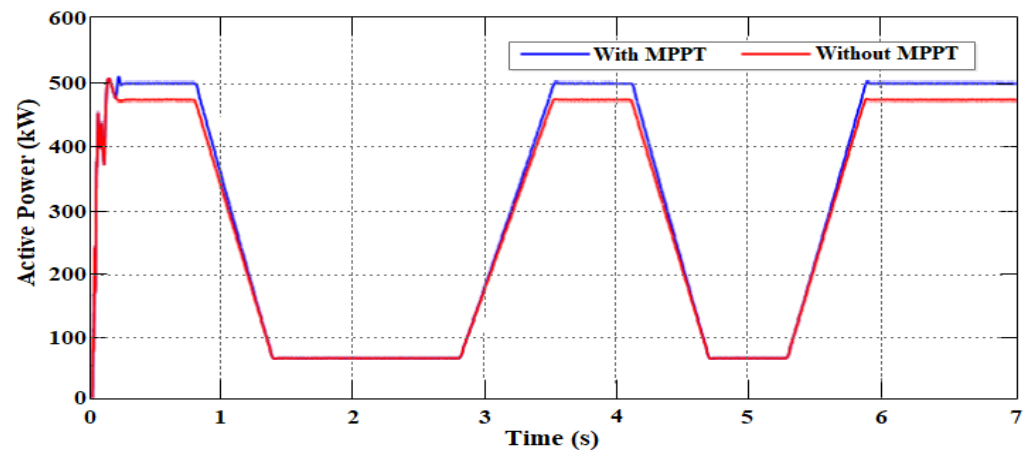

Figure 11. Injected active power from PV station with MPPT and without MPPT algorithm 


\subsubsection{Performance of $P V$ system (A)}

The PV system (A) performance was investigated under changing solar radiation, as shown in Figure 12. During the period of the simulation, the system surface temperature is presumed to be $25^{\circ} \mathrm{C}$. Figure 12(a) presents the variation in solar radiation; it shows the changes in irradiation during the day. Figure 12(b) depicts the active power injected from the PV system into the grid. The power varies with solar radiation, and the reactive power is zero at the unity power factor. The three-phase current injected is shown in Figure 12(c). It was observed that as a function of the injected power, the inverter controller regulates the current amplitude. Figure 12(d) shows the system controller's effectiveness. Consequently, the grid voltage is in phase with the injected current owing to the unity power factor. The duty cycle keeps the output voltage proportional to the set reference voltage. Once the peak power is detected, the MPPT algorithm utilizes a variable duty cycle to reduce the oscillations in injecting power. Figure 13 depicts the boost converter switching duty cycle.

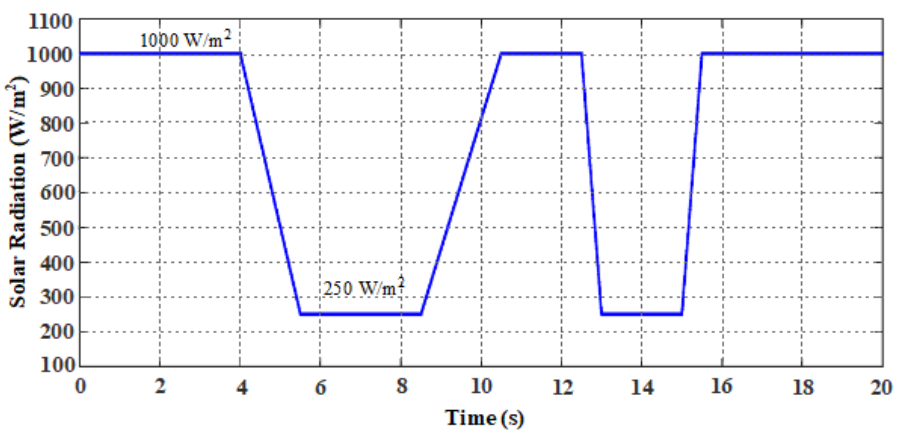

(a)

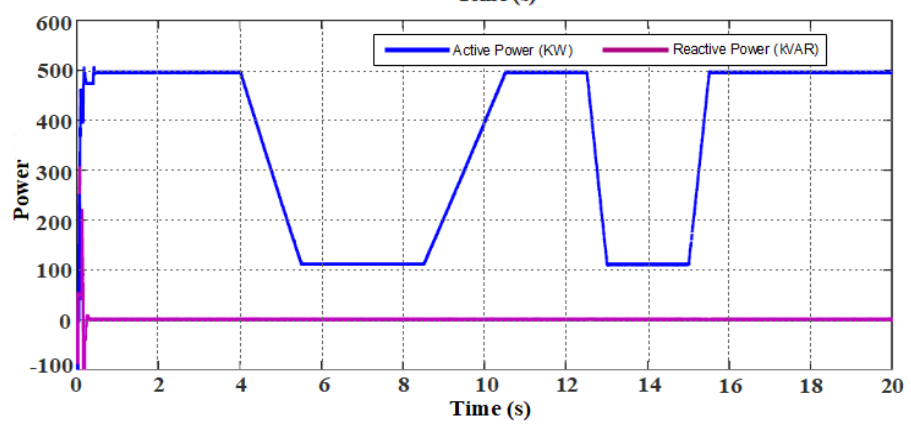

(b)

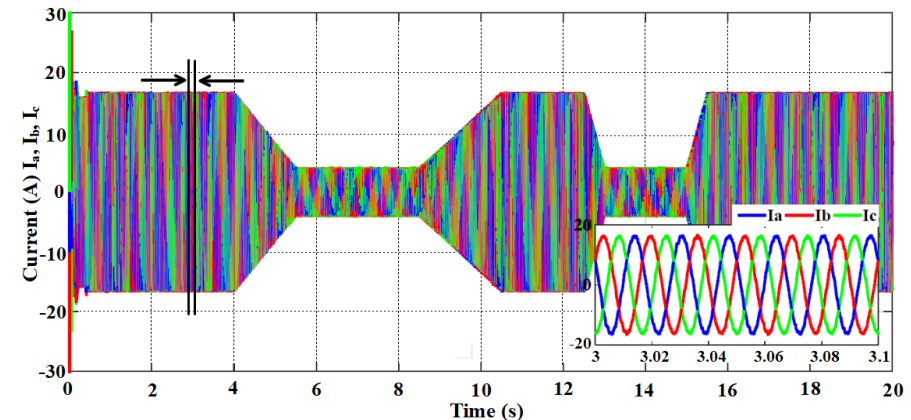

(c)

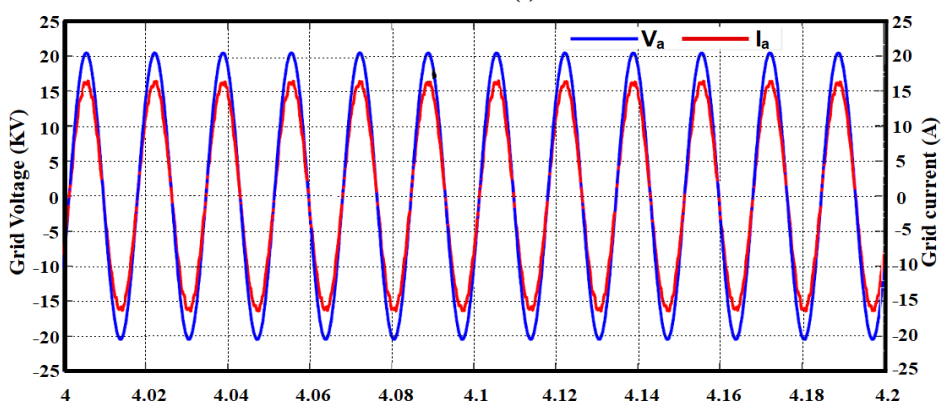

(d)

Figure 12. Performance analysis of the PV system (A), (a) solar radiation variation with time, (b) injected active and reactive power, (c) current injected from the PV system A, (d) PV system (A) injected current 


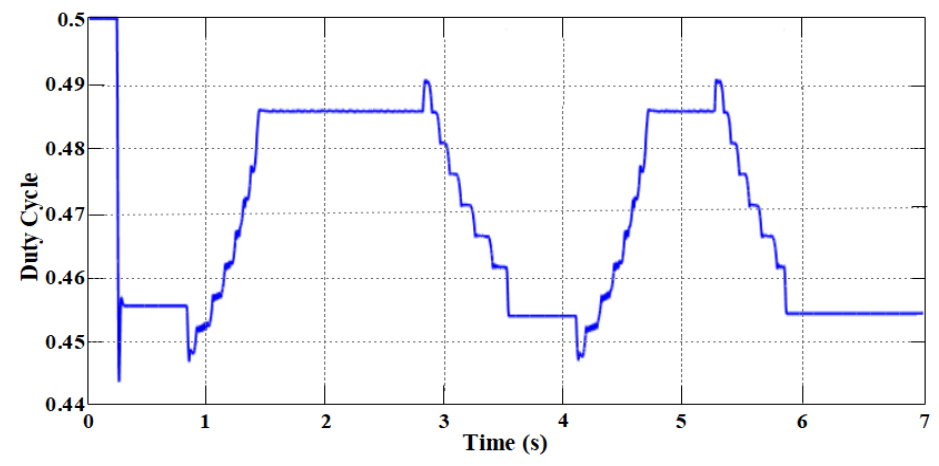

Figure 13. Converter switching duty cycle

\subsubsection{Performance of PV system (B)}

In Figure 14(a) (see in appendix), the performance analysis of the PV system (B) under solar radiation variability is shown. Figure 14(b) illustrates that irrespective of the solar radiation variation, the DC-link voltage controller effectively regulates the DC-link voltage constant at a reference value $(500 \mathrm{~V})$. At unity power factor, almost the same amount of active power gen.erated by the PV array is fed into the grid, as indicated in Figure 14(c). The grid three-phase current is presented in Figure 14(d). The change in the current amplitude indicates the power variation as the grid voltage remains constant. Figure 15 depicts the load voltage at Bus B1; regardless of the solar radiation variation, the load voltage remains constant. It proves the effectiveness of the implemented MPPT control algorithm in responseto sudden changes in weather conditions and the PV system's injected power.

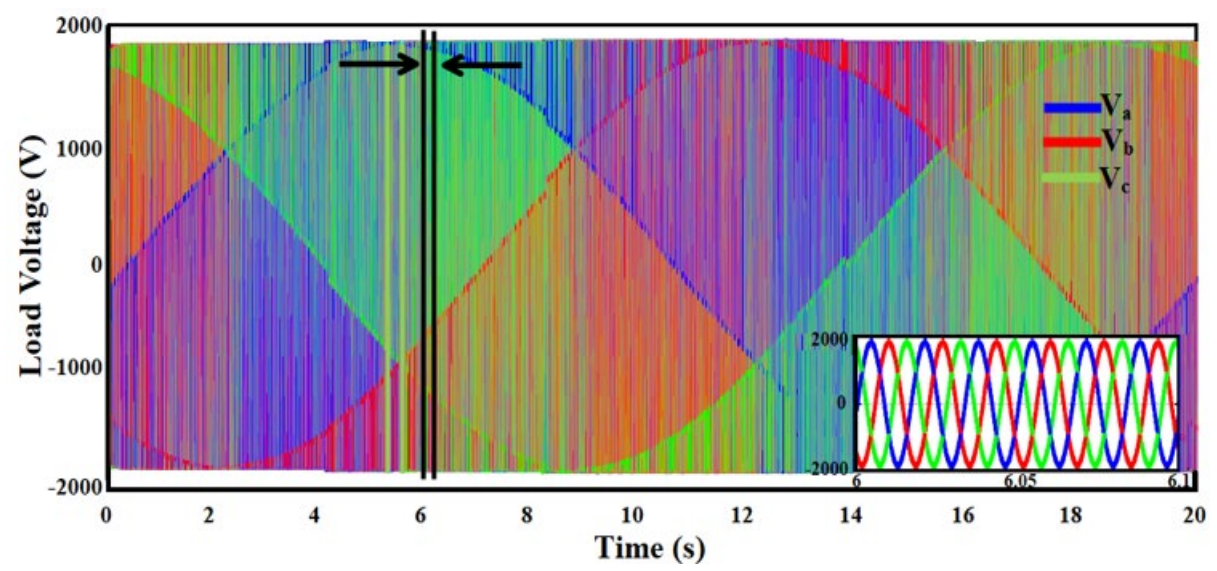

Figure 15. Constant load voltage under weather condition variation

\section{CONCLUSION}

A grid-tied PV system model, simulation, and control have been investigated in this paper. The system model has two PV systems penetrating the grid at different locations, supplying variable loads. For both PV systems, the InCond MPPT algorithm was implemented to extract maximum power under solar radiation variations. The PV array output performance under variable solar radiation has been investigated. As shown, the voltage of DC output and the output current varies due to variable parameters of the input. The converter, however, controls the voltage of the output to a constant value. The PV system's dynamic performance was tested against different levels of solar radiation. The results of the simulation have consistently demonstrated the reliability of the MPPT control method in response to sudden solar radiation variations. Furthermore, the grid's variable load demands were efficiently met by the system power flow.

\section{ACKNOWLEDGEMENTS}

This study is funded by the National Research Foundation (NRF). 


\section{APPENDIX}

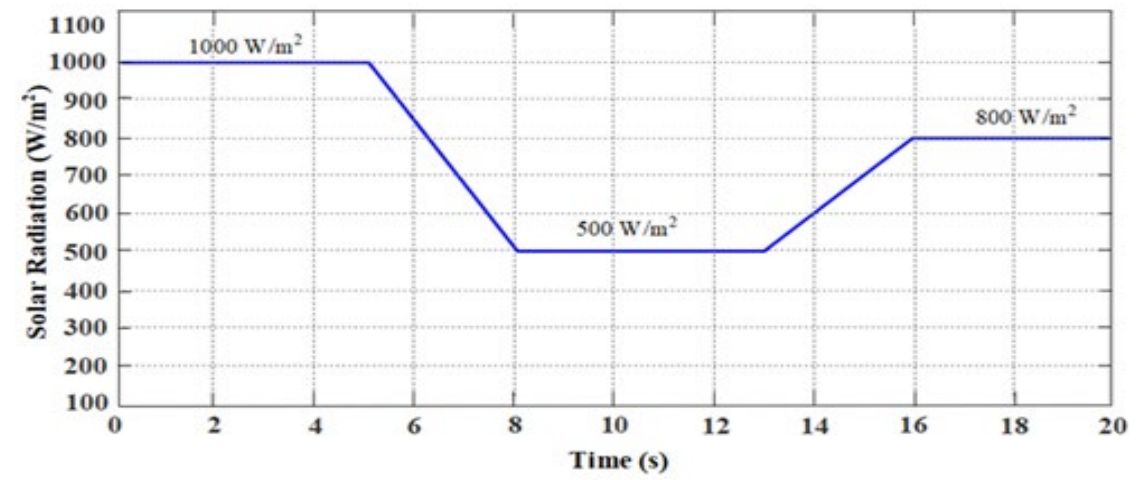

(a)

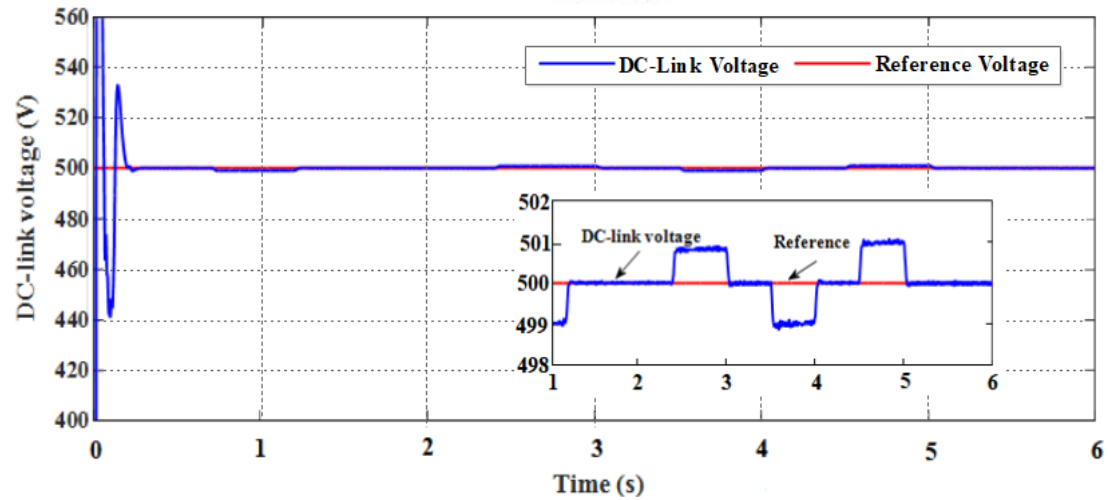

(b)

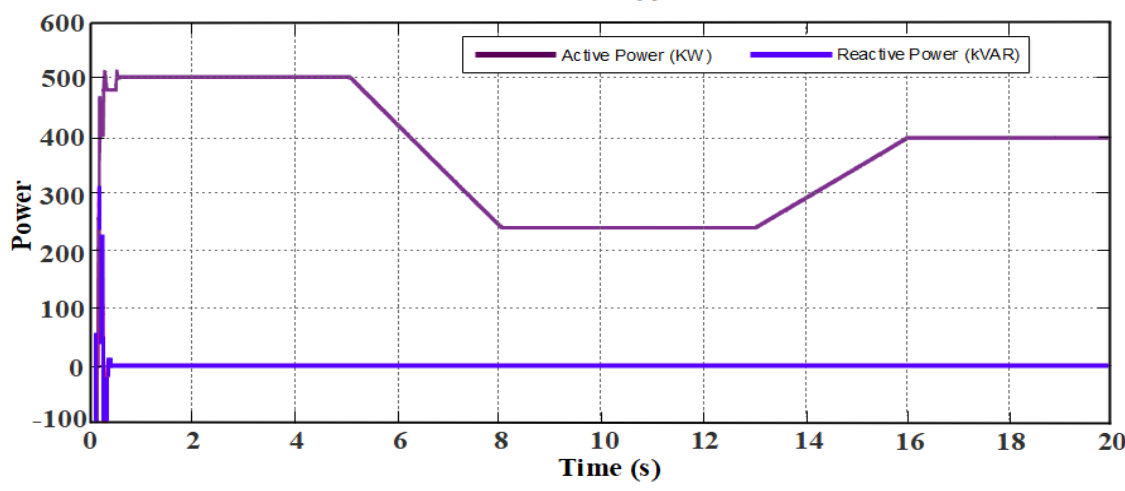

(c)

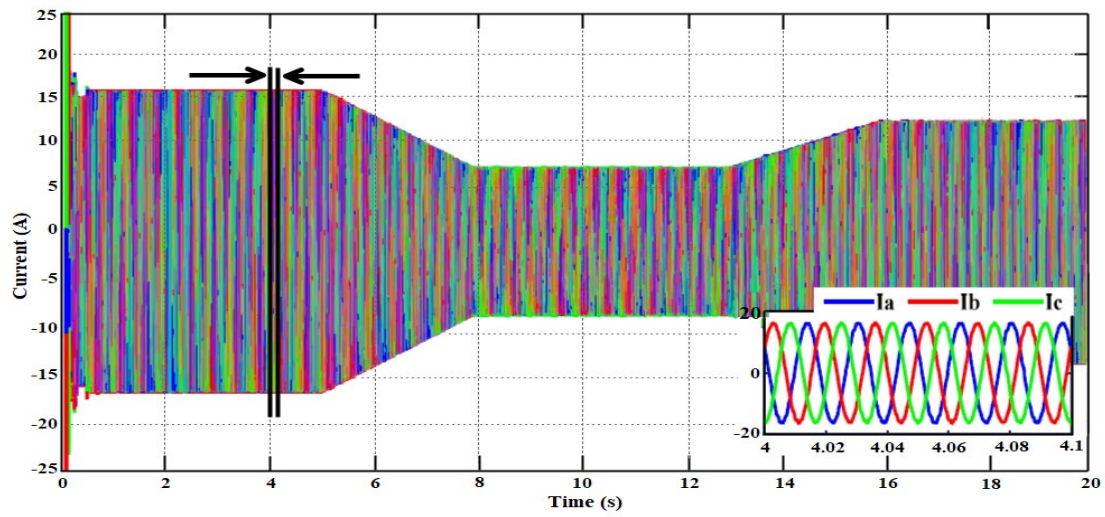

(d)

Figure 14. The PV system (B) performance analysis, (a) Solar radiation variation with time, (b) The reference voltage value of DC-link, (c) Active and reactive power injected into the grid

d) Current injected from the PV system B 


\section{REFERENCES}

[1] D. J. Feldman, M. Zwerling, and R. M. Margolis, "Q2/Q3 2019 Solar Industry Update," National Renewable Energy Laboratory (NREL), 2019.

[2] T. Buckley and J. Sharda, "India's electricity-sector transformation," Institute for Energy Economics and Financial Analysis, 2017.

[3] J. G. Wright, J. R. Calitz, R. Fourie, and L. D. Chiloane, "Integrated Resource Plan 2019: Initial CSIR insights and risks/opportunities for South Africa," Our Future through Science, 2019.

[4] M. Bazilian, P. Nussbaumer, H. Rogner, A. Brew-Hammond, V. Foster, E. Williams, M. Howells, P. Niyongabo, and L. Musaba, "Energy access scenarios to 2030 for the power sector in sub-Saharan Africa," Utilities Policy, vol. 20, no. 1, pp. 1-16, 2012 .

[5] A. Adebiyi, I. Lazarus, A. Saha, and E. Ojo, "Performance analysis of PV panels connected in various orientations under different climate conditions," in Proceedings of the 5th Southern African Solar Energy Conference (SASEC 2018), pp. 46-51, 2018.

[6] A. A. Adebiyi, I. J. Lazarus, A. K. Saha, and E. E. Ojo, "Performance Analysis of 8 kW Grid-Tied Solar Photovoltaic Power Plant in Durban South Africa," International Journal of Mechanical Engineering and Technology (IJMET), vol. 10, no. 4, pp. 82-95, 2019.

[7] H. K. Nunna and D. Srinivasan, "Multiagent-based transactive energy framework for distribution systems with smart microgrids," IEEE Transactions on Industrial Informatics, vol. 13, no. 5, pp. 2241-2250, 2017.

[8] M. H. Albadi and E. F. El-Saadany, "A summary of demand response in electricity markets," Electric power systems research, vol. 78, no. 11, pp. 1989-1996, 2008.

[9] M. Karimi, H. Mokhlis, K. Naidu, S. Uddin, and A. Bakar, "Photovoltaic penetration issues and impacts in distribution network-A review," Renewable and Sustainable Energy Reviews, vol. 53, pp. 594-605, 2016.

[10] P. Chaudhary and M. Rizwan, "Voltage regulation mitigation techniques in distribution system with high PV penetration: A review," Renewable and Sustainable Energy Reviews, vol. 82, pp. 3279-3287, 2018

[11] F. M. Camilo, R. Castro, M. E. Almeida, and V. F. Pires, "Assessment of overvoltage mitigation techniques in lowvoltage distribution networks with high penetration of photovoltaic microgeneration," IET Renewable Power Generation, vol. 12, no. 6, pp. 649-656, 2018.

[12] E. Demirok, D. Sera, R. Teodorescu, P. Rodriguez, and U. Borup, "Clustered PV inverters in LV networks: An overview of impacts and comparison of voltage control strategies," in 2009 IEEE Electrical Power \& Energy Conference (EPEC), Montreal, QC, pp. 1-6, 2009.

[13] F. Rezaei and S. Esmaeili, "Decentralized reactive power control of distributed PV and wind power generation units using an optimized fuzzy-based method," International Journal of Electrical Power \& Energy Systems, vol. 87, pp. 27-42, 2017.

[14] M. Oshiro et al., "Optimal voltage control in distribution systems using PV generators," International Journal of Electrical Power \& Energy Systems, vol. 33, no. 3, pp. 485-492, 2011.

[15] L. Hassaine, E. OLias, J. Quintero, and V. Salas, "Overview of power inverter topologies and control structures for grid connected photovoltaic systems," Renewable and Sustainable Energy Reviews, vol. 30, pp. 796-807, 2014.

[16] J. Petinrin and M. Shaabanb, "Impact of renewable generation on voltage control in distribution systems," Renewable and Sustainable Energy Reviews, vol. 65, pp. 770-783, 2016.

[17] A. S. Samosir and H. Gusmedi, "Modeling and simulation of fuzzy logic based maximum power point tracking (MPPT) for PV application," International Journal of Electrical and Computer Engineering (IJECE), vol. 8, no. 3, pp. 1315-1323, 2018

[18] R. B. Koad, A. F. Zobaa, and A. El-Shahat, "A novel MPPT algorithm based on particle swarm optimization for photovoltaic systems," IEEE Transactions on Sustainable Energy, vol. 8, no. 2, pp. 468-476, 2016.

[19] I. Yadav, S. K. Maurya, and G. K. Gupta, "A literature review on industrially accepted MPPT techniques for solar PV system," International Journal of Electrical \& Computer Engineering (IJECE), vol. 10, no. 2, pp. 2117-2127, 2020.

[20] A. Loukriz, M. Haddadi, and S. Messalti, "Simulation and experimental design of a new advanced variable step size Incremental Conductance MPPT algorithm for PV systems," ISA transactions, vol. 62, pp. 30-38, 2016.

[21] I. W. Christopher and R. Ramesh, "Comparative study of P\&O and InC MPPT algorithms," American Journal of Engineering Research (AJER), vol. 2, no. 12, pp. 402-408, 2013.

[22] S. Gautam, D. B. Raut, P. Neupane, D. P. Ghale, and R. Dhakal, "Maximum power point tracker with solar prioritizer in photovoltaic application," in 2016 IEEE International Conference on Renewable Energy Research and Applications (ICRERA), Birmingham, pp. 1051-1054, 2016.

[23] A. A. Adebiyi, A. K. Saha, I. J. Lazarus, and E. E. Ojo, "Investigation to Determine the Impacts of SPV Penetration on an Unbalanced Distribution Grid," in 2019 IEEE PES/IAS PowerAfrica, Abuja, Nigeria, pp. 116-120, 2019.

[24] A. A. Adebiyi, I. Lazarus, A. K. Saha, and E. E. Ojo, "High PV Penetration Impact on an Unbalanced Distribution Network," in 2019 IEEE PES/IAS PowerAfrica, Abuja, Nigeria, pp. 706-710, 2019

[25] A. H. Ali, H. S. Hamad, and A. A. Abdulrazzaq, "Performance Investigation of Grid Connected Photovoltaic System Modelling Based on MATLAB Simulation," International Journal of Electrical and Computer Engineering (IJECE), vol. 8, no. 6, pp. 4847-4854, 2018.

[26] B. A. Allah and L. Djamel, "Control of Power and Voltage of Solar Grid Connected," International Journal of Electrical and Computer Engineering (IJECE), vol. 6, no. 1, pp. 26-33, 2016.

[27] B. E. Strand, "Voltage Support in Distributed Generation by Power Electronics," Institutt for elkraftteknikk, 2008.

[28] W. Kou, D. Wei, P. Zhang, and W. Xiao, "A direct phase-coordinates approach to fault ride through of unbalanced faults in large-scale photovoltaic power systems," Electric Power Components and Systems, vol. 43, no. 8-10, pp. 902-913, 2015.

Performance analysis of grid-tied photovoltaic system under varying weather ... (Abayomi A. Adebiyi) 


\section{BIOGRAPHIES OF AUTHORS}

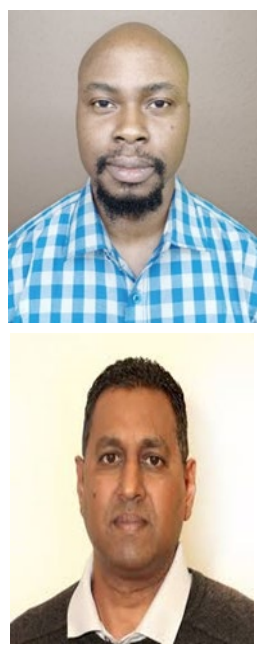

Abayomi Aduragba Adebiyi is a doctoral degree student at Durban University of Technology, South Africa. He received his Higher National Diploma in Electrical and Electronics Engineering Technology at Kwara State Polytechnic, Ilorin, Nigeria, in 2006 and Master of Engineering degree in Electrical Power Engineering from the Durban University of Technology, South Africa in 2017. $\mathrm{He}$ worked in the Department of Electrical and Information Engineering (EIE) at Covenant University, Nigeria, and Durban University of Technology, South Africa. He has published Scopus indexed journal articles and conference papers. His areas of research interest are power system, renewable energy, and optimization of renewable energy systems. He supervises Master's degree students in renewable energy.

Ian Joseph Lazarus is an Associate Professor at the Department of Physics at the Durban University of Technology. He is the Project Leader at KZN Industrial Energy Efficient Training \& Resource Centre. He had his BSc at the University of Durban Westville (UDW), majoring in Mathematics and Physics. He received an Honours degree in Physics at the University of Cape Town (UCT), followed by a Master's degree in Nuclear Physics at UDW. His doctoral degree was completed at the University of KwaZulu-Natal, South Africa, in the field of Plasma Physics, focusing on linear and nonlinear wave phenomena in electron-position plasmas. He has a Diploma in Wind Energy Use (Sweden). His research areas in plasma physics, renewable energy, and physics education. He supervises Master and Doctoral degree students in renewable energy and plasma physics. He has published journal articles and international conference papers.

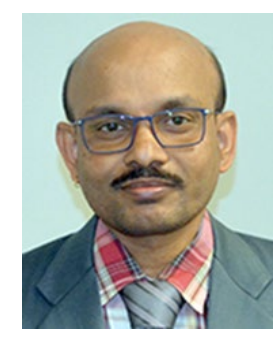

Akshay Kumar Saha is an Associate Professor, Academic Leader Research, and Higher degree in the School of Engineering at Howard College Campus, Electrical, Electronic, and Computer Engineering at the University of KwaZulu-Natal, Durban, South Africa. He is a Senior Member of SAIEE, SAIMC, and an Individual Member Cigre. Also acting as an Editorial Board Member for International Journals. He is responsible for teaching both undergraduate and postgraduate courses in Electrical Engineering and research at postgraduate levels. He was awarded the Best Lecturer Electrical Engineering in 2013, 2014, 2016, 2017, and 2018 by the School of Engineering and Research Excellence Award in the years 2015, 2016, and 2017 by the University of KwaZulu-Natal. His research area is electrical power systems, applications of power electronics in power systems, renewable energy \& distributed energy resources in power systems, applications of artificial intelligence in power systems, high voltage power systems, and engineering education. He has published journal articles, including transactions in IEEE and IET, and over 90 international conference papers.

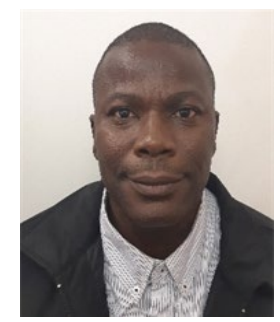

Evans Eshiemogie Ojo is a Senior Lecturer at the Department of Electrical Power Engineering, Durban University of Technology. He received both his Master's degree and a Ph.D. degree in Electrical Engineering from the University of KwaZulu-Natal, South Africa. He has published a book chapter, journal articles, and international conference papers. He supervises Master and Doctoral degree students in Electrical Power Engineering. His research interest is powerline conductors, finite element analysis, and renewable energy. 